\title{
A Controversial Role Model for Pakistani Women
}

\author{
Faiza Mushtaq
}

\section{OpenEdition}

\section{Journals}

Electronic version

URL: https://journals.openedition.org/samaj/3030

DOI: 10.4000/samaj.3030

ISSN: 1960-6060

\section{Publisher}

Association pour la recherche sur l'Asie du Sud (ARAS)

Printed version

ISBN: 1960-6060

\section{Electronic reference}

Faiza Mushtaq, "A Controversial Role Model for Pakistani Women", South Asia Multidisciplinary

Academic Journal [Online], 4 | 2010, Online since 05 April 2018, connection on 21 September 2021 URL: http://journals.openedition.org/samaj/3030 ; DOI: https://doi.org/10.4000/samaj.3030

This text was automatically generated on 21 September 2021.

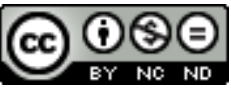

This work is licensed under a Creative Commons Attribution-NonCommercial-NoDerivatives 4.0 International License. 


\title{
A Controversial Role Model for Pakistani Women
}

\author{
Faiza Mushtaq
}

1 Al-Huda opened its first school of Islamic education in Islamabad in 1994. The institute branched out to Lahore and Karachi over the next few years and by now its network has grown to approximately 70 locations in urban areas all over Pakistan. More than 15,000 women ${ }^{1}$ have graduated with a diploma or certificate from one of Al-Huda's courses while many more attend these lessons without enrolling formally. In addition, classes under the Al-Huda banner are carried out amongst Pakistani diaspora communities in North America, Europe, the Middle East and East Asia. The founder and leader of this movement is a woman called Dr. Farhat Hashmi². Her teachings form the core of study in Al-Huda classrooms and her lectures can attract audiences numbering in the thousands. Her message and fame are carried far and wide through audio cassettes and CDs, books and pamphlets, radio and television programs, and websites.

2 The curriculum at Al-Huda focuses on the texts of the Quran and Hadith, ${ }^{3}$ including translation from Arabic into Urdu and Hashmi's extensive commentaries on their meaning, historical context and contemporary relevance. These lessons train women so they can understand and apply canonical Islamic teachings to their own lives, reform themselves, and then share this knowledge with others (Hashmi 2006). Farhat Hashmi's interpretations are marked by the particular doctrinal stance that is identified as the Ahli Hadith branch of Sunni Islam in South Asia. This is a puritanical school of thought that rejects most customary practices and intermediaries to privilege foundational texts and individual religious responsibility. ${ }^{4} \mathrm{Hashmi}$ also advocates non-religious education for women, preaches the value of scientific reasoning and logic, and uses modern management and marketing tools in organizing Al-Huda.

3 This combination of old and new forms of knowledge, of modern and traditional approaches to religious practice, has attracted urban educated women from Pakistan's upper and middle classes. Many of them take up teaching and administrative positions across Al-Huda's organizational network, volunteer for its social welfare projects, or stay involved with the group on an informal basis. The wealthy amongst them also make 
sizable donations of money and property which sustain the movement. Enthusiastic AlHuda participants are animated by a deep admiration for Farhat Hashmi and by a desire to emulate her exemplary qualities of scholarship and piety. However, their willingness to accept her moral authority and alter their behavior is troubling for some of their contemporaries.

In this paper, I explore how Farhat Hashmi comes to hold the status of a role model for some women in Pakistan while others fail to be swayed by her appeal and are deeply hostile to her reformist mission. The opening sections analyze the social backgrounds of Hashmi as well as her support base, and are followed by a discussion of her opponents' views. Al-Huda and Hashmi attract criticism from amongst various social groups in Pakistan but here I focus on two of the most vocal ones: the religious experts who have traditionally been in charge of Islamic institutions of learning, and the urban secularliberal elites.

5 My analysis highlights the central role of social relationships and the interactions that AlHuda students and teachers have with each other which convert them into Hashmi's committed followers. The leader does not achieve her authoritative standing through a collection of static personal attributes. Instead, it is through her organizational innovations that her qualities can be displayed in recurrent collective experiences, where participants see her in action, feel the effects of authority, talk about it, and form bonds with others around them. In other words, Al-Huda's institutional activities are crucial in turning Hashmi into a role model for her students and providing them with meaningful routines to carry over into their day-to-day lives.

6 Hashmi has built her appeal by deliberately distancing and contrasting Al-Huda with madrasas (Islamic religious schools) and other groups that provide Islamic education in Pakistan. Observers of Al-Huda also tend to highlight the 'uniqueness' of its accomplishments (Ahmad 2009: 1). However, the success of this movement has to be evaluated in light of its proximity to, and borrowings from, its contemporary rivals and historical predecessors. This context shapes the expectations and judgments formed about the movement by supporters and opponents alike.

$7 \quad$ My analysis is built upon twenty months of fieldwork at Al-Huda branches in three cities of Pakistan-Karachi, Lahore and Islamabad-as well as a week spent with Al-Huda in Toronto. These ethnographic observations are supplemented by formal interviews with Farhat Hashmi, Al-Huda students and staff members, and other key informants, textual material produced by Al-Huda, official records, and secondary literature. ${ }^{5}$

\section{Leading by example}

The official Al-Huda biographical sketch of its founder presents Farhat Hashmi as a figure dedicated to the service of Islam and motivated by her love of learning. Hashmi was born in Sargodha ${ }^{6}$ in 1957 as the eldest of twelve siblings, and she credits her father as being the most important influence in her early life. Abdur Rehman Hashmi was a lifelong member and local leader of the Jama'at-i-Islami ${ }^{7}$, and he taught his children the Quran and basic tenets of Islam at home. Farhat Hashmi herself was a head of the Jama'at's student wing while she attended college in Sargodha. She received a Masters degree in Arabic from the University of Punjab in Lahore, and went on to marry a fellow student, Idrees Zubair. Both of them then taught at the International Islamic University (IIU) in 
the capital city of Islamabad, before proceeding together to the University of Glasgow to obtain their PhD degrees in Islamic Studies. During this period, they also traveled in Turkey, Jordan, Syria, Egypt and Saudi Arabia, visiting libraries and meeting with prominent Islamic scholars. Shortly after returning to Islamabad, Hashmi left her position at IIU and converted her informal Quran lessons in women's homes into a fullfledged institute, i.e. Al-Huda, offering year-long structured courses of study. Her husband and daughters have also been involved with teaching at Al-Huda and have now followed her to Toronto where the school has opened a large branch.

9 Hashmi's journey from the small provincial town of Sargodha to big cities like Lahore and Islamabad would have been less likely a generation ago, and was paved by Pakistani women's increasing access to higher educational opportunities in public-sector schools like Punjab University and the International Islamic University. Her life as a student, teacher and administrator at these two institutions brought her into close contact with the dominant social discourses and state-sanctioned forms of associational life. This was the time of General Zia's rule (1977-1988), when the Jama'at-i-Islami found official favor, Arabic training was encouraged and funded by the state, and Saudi Arabia was an important source of patronage and normative guidance. The tentative gains in female education and employment opportunities were confined to a few permissible fields and remained conditional upon women's acceptance of moral regulation (in their appearance, conduct and spatial segregation) by male authority.

Hashmi chose to distance herself from the Jama'at-i-Islami's political agenda when she launched her own teaching career, and the official narrative of her life makes no mention of her own or her family's links with the Jama'at. Yet that early involvement clearly helped shape her conviction that individual disciplining and righteous lifestyles are the first step towards social reform, and exposed her to tools like study circles, pamphlets and Islamic literature towards attaining that goal. Travel to the United Kingdom and the Middle East gave Hashmi greater exposure to global networks of Islamic scholarship and modern pedagogical methods, both of which have a clear imprint on Al-Huda's organization. Her critiques of madrasa education and the practices of Shi' ${ }^{8}{ }^{8}$ and Barelwi ${ }^{9}$ groups show clear sectarian influences from Saudi ulama and the Ahl-i Hadith, but are also shaped through interactions with the state and educational institutions in Pakistan.

11 There is nothing immediately striking about Hashmi's personal appearance. She comes to her classes in casual dress, with muted makeup and few items of jewelry, and covers her head with a loosely-draped colored scarf matching her outfit. ${ }^{10}$ She is tall and heavy-set, in her early fifties, and wears large round reading glasses. Outside school she is seen in full hijab: an ankle-length black outer robe on the body and black scarf covering most of the head and face (niqab or face veil), leaving only the eyes exposed. This is how she appears to outsiders on television and in printed images, and only women who have attended a lecture or met her in some other capacity are familiar with her face. Her calm and measured voice is thus a much more recognizable feature to anyone who has heard one of her tapes or encountered a lecture on radio or television. Notably, men are also included in this extended audience although they cannot physically attend her lectures. A number of Al-Huda staff members confirmed that both male and female students register for the distance-learning course, and male prison inmates occasionally send letters of appreciation to the organization after being provided Hashmi's tapes. There is a strand of conventional Islamic reasoning that considers the female voice to be sexually arousing, dangerous, and subject to restrictions (Mahmood 2005: 65-66, Hirschkind 2006: 111), 
which is contravened by the public availability of Hashmi's religious lectures for both sexes.

Hashmi commanded the undivided attention of listeners in every large or small Al-Huda group I observed. Audience members would be scribbling furiously in their notebooks in an attempt to take down every word, or otherwise following along in their open books, and it was rare to find signs of distraction. Hashmi delivers her lectures at a brisk pace in conversational Urdu peppered with English words and phrases and interspersed with fluently recited Arabic verses. Certain standard elements are present in every lecture: urging devoted study of the Quran, Hadith and Arabic language; presenting lessons from the life of the Prophet Muhammad and other figures from Islamic tradition; including examples from current affairs, everyday experiences and her own life; inculcating techniques of self-examination and virtuous conduct.

Lambek (1990: 25) argues that mastery of abstract, written textual knowledge 'is necessary for wielding religious authority [but]... is far from sufficient', and it makes the bearer's conduct subject to more stringent demands. Personal performance has to satisfy community standards and ethical imperatives before it becomes legitimate, and is also judged by the consequences it generates (Lambek 1990: 28-33). Similarly, many women in Pakistan who spoke to me in interviews about the appeal of Al-Huda, singled out Farhat Hashmi's ability to communicate and connect with them in a way that other teachers and religious leaders have not done. All bring some implicit or explicit comparisons to their experiences with Al-Huda, including their school and college studies, childhood Quran lessons or other interactions with maulvis (ritual prayer leaders), dars (Islamic lessons), offered by Islamist parties and other women preachers, and televised or taped sermons and books by well-known Islamic figures.

14 Samar, ${ }_{11}^{11}$ a senior Al-Huda teacher in Karachi, explains how she had been reading various translations of the Quran on her own and thought she knew her religion well, but 'the spirit' had been missing. Once she heard Hashmi speak, she says, 'it affected my heart immediately'. She claims this is because 'she speaks at your own intellectual level, I mean, somebody who you could relate to... The Quran is of course a timeless book... she makes it relevant for us'. Kiran, another Al-Huda graduate from Islamabad and current instructor in Karachi, says she often used to go to class and feel that 'Dr. Farhat is speaking about me. That's the feeling we all get. Like she knows something about me and what I'm going through these days and this is why, exactly, she's just speaking to me'.

Praise for Hashmi's knowledge is commonly accompanied by the perception of her sincerity, leading many women to believe that she is only giving them direct and transparent access to the word of God. If she had wanted to mislead them, according to this logic, she would not have taught them Arabic, and they trust her interpretation of the texts because they have some tools to judge it with. Mehnaz, a student and donor at Al-Huda in Karachi, claims Hashmi has no 'sectarian bias..., [has] complete openness to anyone and everyone', and this assessment is shared by many of my respondents. This unifying theme in the face of sectarian conflict is a prominent part of Al-Huda's pitch, and is typical of Ahl-i Hadith (and other Salafi) groups (Meijer 2009).

16 Al-Huda women's testimonials describe their newfound ease at adopting virtuous practices, and cite similar transformations they have seen in multiple others. Frequently used metaphors include being shown a mirror in which the flawed self becomes revealed, and an opening of the heart after which God becomes closer. The most visible change in these women involves their adoption of some form of veiling, and giving up practices like 
listening to music or watching entertainment shows on television. ${ }^{12}$ Bushra, who teaches a weekly class at Al-Huda in Lahore, quoted this verse from the Quran: 'I have made it easy for you to take a reminder from the Quran: is there anyone to take this reminder?' (54: 17). She reflected that 'you have to be pure before you can take the reminder... that's what Dr. Farhat does for us, she interprets the Quran so purely for us, helps us relate to the example of Rasul Allah [the Prophet of God, i.e. Muhammad]..., we get hooked'. This dynamic, according to her, extends from individual transformation to collective experience, and becomes 'the binding force between us... keeps us together'. Some of my respondents bring up the resistance and hostility others show towards Al-Huda, and explain it as a willful misunderstanding of Hashmi's message. They sound confident that once the skeptics listen to her attentively they will start to act differently, and will come to share their moral concerns.

Hashmi is modest about her achievements, and shares the credits for Al-Huda's success with her followers: 'It's not like I have done this alone, it's been a collective effort from all of us... it's the students who open up new branches... I just go wherever I'm called' (Hashmi 2006). She has explained her mission as wanting to "help others experience the peace I felt by reading the Koran [sic]... When people benefit from something, they will be drawn to it' (Ali 2003). She promises women 'both spiritual benefit and practical guidance' in her lessons (Gulf News 2002), and many of her supporters echo her words when describing her influence. A number of women dwelt on the theme of discipline and effort demanded by the grueling schedule of studies at Al-Huda which gradually becomes rewarding. They mention how Hashmi gave them the confidence to go out and teach the Quran, giving them the chance to lecture in class while they were her students.

Sympathetic observers report that Hashmi's 'soothing style articulates a message of personal reform. She reminds listeners of God's mercy and forgiveness-in stark contrast to the dire warnings of hellfire favored by some mullahs' (Khan 2004), and that 'hearing Dr Hashmi is a cerebral experience... She is tolerant, abreast with what is going on in the world today and most of all not racist at all' (Karachian 1999). This praise often betrays prior assumptions and comparisons against which Hashmi is judged: she is 'a mild and soft-spoken lady who has none of the fiery disposition that the uninformed liberals would expect' (Hussain 2000), and 'herself speaks usually about broader concerns' unlike other women at religious gatherings (Hyat 2001).

\section{The support base for Al-Huda}

The influence of Al-Huda as a movement reaches some social groups in Pakistan more readily than others. Gender is a dividing line, although men can access the teachings of the group even if they cannot physically participate in its gatherings. The urban locations of movement activities and the requirement of literacy place significant limits on who can join. These two factors mediate the impact of women's socio-economic backgrounds, and decisively shape the boundaries of Al-Huda's target audience.

The types of urban neighborhoods, where Al-Huda activities tend to cluster, contain important demographic indicators. In Karachi for instance, these areas include Clifton and Defence Housing Authority (DHA), which are by and large 'inhabited by the elite of the city... [comprising of] bureaucrats, politicians, business executives and industrialists' (Hasan 1999: 169). Other popular locations are in PECHS, ${ }^{13}$ North Nazimabad, Federal B Area, and Gulshan-i Iqbal-'predominantly middle-income residential areas... [where] 
most of the residents work as middle level functionaries in banks, offices, factories in the city centre, the port or in the industrial estates' (Hasan 1999: 169). At least $50 \%$ of Karachi's population is estimated to live in its unplanned informal settlements (Hasan 1999: 166), and there is no Al-Huda branch catering specifically to them.

The list of Al-Huda locations in other Pakistani cities similarly ranges across upper- and middle-income neighborhoods. ${ }^{14}$ The chosen locations target residents who are not readily persuaded to leave their affluent enclaves and venture into other areas of their city, whether for work or recreation. The reverse, however, is not true and some of the women from poorer localities who do travel to Al-Huda branches have the option to stay in attached hostels. There are differences of age and class background among Al-Huda participants, and their composition is not as homogenous as it might appear from the outside. Some of the women hail from wealthy families, and make sizable donations of money and property to Al-Huda, others require financial support in order to afford these classes, and many are simultaneously engaged in other educational or occupational careers.

In the early years of Al-Huda's diploma course, a bachelor's degree was the minimum qualification required of incoming students. This condition was relaxed over time as the number of course offerings and the pool of applicants expanded. Now some Al-Huda programs accept the intermediate degree that colleges in Pakistan confer after twelve years of formal schooling, while others accept students who have completed ten years of education and matriculated from high school. Considering that only $32 \%$ of Pakistan's total adult female population and $55 \%$ of urban women meet the criteria of basic literacy (UNESCO 2004: 7), those who finish high school or above are still in a minority.

The wealthy elites, who used to dominate Al-Huda gatherings in the early yearsprofessional women, as well as wives of senior military officials, government bureaucrats and industrialists-, are increasingly joined by representatives from middle-income urban groups. Members of the movement widely share a belief that they are part of an 'educated class', ${ }^{15}$ and thus responsible for setting the standards of moral conduct for the rest of society. Farhat Hashmi's lectures and Al-Huda class sessions frequently cite scriptural sources to argue that those who possess knowledge, resources, or other capabilities also bear greater responsibilities and accountability. I heard many of my respondents repeat the same line of reasoning to deflect criticism about Al-Huda's elitism and to justify differences of social class and status. Nasreen, a regional coordinator for the organization in Karachi, claims they held programs in a five-star hotel only because the spacious halls could accommodate women 'from all walks of life' and, moreover, the domestic servants some women brought in with them to listen to the Quran 'would never have entered that hotel for any other reason'. She continues: 'But rich and educated people are the trend-setters, you can't debate that... if a woman in Lalukhet ${ }^{16}$ starts wearing the hijab... what impact will it have?' Tahira, an associate of Hashmi's from the early days of Al-Huda in Islamabad, argues that the cultural endorsement and material resources of elites are necessary to achieve the movement's mission of widespread social reform.

24 Al-Huda consists of urban, literate women who believe that their education sets them apart from others in society whom they judge to be illiterate, rustic and morally suspect. They are aware of differences in class and status within their own ranks, and read them through indicators such as place of residence, style of dress, language-especially command over English-and manner of speech. However, they also emphasize what they 
have in common as participants in the movement: their mastery of text-based knowledge, the scholarly qualities of their leader Hashmi, and the discipline and moderation acquired through their program of character training. Both the formal presentations and informal conversations within the movement tend to portray condemned, sinful or un-Islamic practices with connotations of backwardness, irrationality and parochialism. In contrast, their own piety and religious knowledge are marked as being rational, analytical, scientific, literal and modern. In one sweep, they distance themselves from the religious learning of the madrasa system while also claiming superiority over the secular educational institutions whose practices they validate. In other words, participation in Al-Huda provides socially recognized symbolic capital to those who are desirous of improving their worldly status as well as to those who are already privileged.

Social networks play an important role in disseminating information about Al-Huda. Most of my respondents heard about Hashmi or her tapes and classes through relatives, friends, neighbors or casual acquaintances. A majority of women attend their first AlHuda gathering because someone else suggests it or accompanies them to it. However, their reasons for staying and for deciding to become more fully involved differ not only from one person to the next but also over time for each individual. Women might join AlHuda classes because of the boredom, lack of personal fulfillment or elitist concerns that some observers ascribe to them (e.g. Ali 2003, Matri 2003, Hyat 2001), but also due to a variety of other personal motivations, biographical turning points or circumstances. What they learn through their interactions in these Al-Huda settings, and the ties they form with other participants, create new sympathies, and shape the future course of their increasing or decreasing involvement. This finding echoes the conclusions that Munson (2002) reaches in his study of participants in the American pro-life movement. He shows how some form of personalized contact through their social networks initially draws individuals to the movement, rather than any concerns over abortion or any pre-existing pro-life beliefs. It is only after an initial period of activism that these individuals come to understand and identify with a pro-life position, and develop into committed activists. To understand why some individuals are mobilized and others are not, 'both the focus on individual attributes and on the [macro-level] political process are inadequate' (Munson 2002: 6).

It is also useful to remember Randall Collins' (2001: 30) warning about 'draw[ing] too sharp a dichotomy between excitement-seeking...participants, and the 'morally serious' participants who come out of a deeper sense of need or dedication'. Instead, he sees a continuum along which the ephemeral and the most deeply committed participants of any movement are arrayed. I also found an ongoing, evolving process by which women's commitment towards Al-Huda's goals is shaped, rather than a one-time decision or a single underlying motivation for joining. Individual women bring with them a variety of beliefs and expectations which end up getting modified, reinforced or unlearned through their recurrent participation in group activities. The communication of ideas and the generation of emotional bonds are both crucial mechanisms in helping forge new concerns and new ways of acting.

There are many ways in which the effects of sustained involvement with Al-Huda manifest themselves in women's self-perceptions, behavior patterns and social relations. One important consequence of the classroom experience is to cast women from different generations, family backgrounds and social profiles in the mold of students. This a departure from the familial bonds and imagery common in some other Islamist groups 
where participants address each other as 'sisters' and 'brothers' ${ }^{17}$ Familial networks are not altogether absent from Al-Huda gatherings, where one finds many mothers and daughters, cousins or other such members of kin groups attending together. However, in the classroom and across the Al-Huda network, these ties are superseded by loyalty towards Hashmi, and women come to relate to each other as fellow students. They look up to Hashmi not as a maternal figure but as a scholar and teacher they all share. The alternative community thus created is fired up by a zeal and higher purpose, and it can potentially override members' other social relations or obligations. The students willingly subject themselves to the demands and discipline of study, and I witnessed many classroom interactions where the request for more homework assignments or additional study sessions was put forward by students rather than teachers. Many women cite the active and engaged participation of students and the chance to learn the Quran collectively, not alone at home, as adding to Al-Huda's appeal.

\section{The ulama's response to dangerous innovations}

d dubious research on Islam, with the aim of marginalizing traditional Islamic scholarship and the role of religion in public life. In this view, Farhat Hashmi's PhD degree from a university in Glasgow under supervision from non-Muslims does more to discredit her than to certify her expertise or authority for interpreting core Islamic texts. They believe her teaching is dangerous because she can corrupt one's entire faith by introducing even one wrong belief or insidious thought. In rejecting Hashmi's authority, the ulama explicitly invoke the weight of their own qualifications and the historical evolution of their role as guardians of sacred knowledge. They compare their lifelong specialized training to the highly skilled work of professionals like doctors, engineers and lawyers, and point out how absurd it would be for laymen to start practicing in those fields. Neither Hashmi nor her students at Al-Huda have gone through the required eight-year basic course of study (dars-i Nizami) taught in South Asian madrasas, and these critics are especially offended by Al-Huda women who start teaching the Quran after a one- or twoyear short course. They find the method of teaching at Al-Huda to be problematic as it relies only on direct translation of the Quran, ignoring the technical principles of Arabic grammar and rhetoric, Islamic theology and jurisprudence, and the scholarly opinion, debates and consensus developed over 1400 years of intellectual history (Abu Safwan 2003: 40-56). The ulama claim that they are carrying on the tradition of the Prophet Muhammad in providing guidance to Muslims through their exemplary practice, while Hashmi practices a religion of expediency, convenience and fabrications (Shabbir 2009). 

writings of these ulama and their followers. They condemn her for not obeying the norms of modesty (purdah), pointing out her inappropriate appearances on the media-where she lets her voice be heard by male strangers-and international travel without a proper male escort (Abu Safwan 2003: 112-5). They disagree strongly with Hashmi's interpretation of Islamic custom that allows women to pray at a mosque rather than in the privacy of their homes, and use voluminous scriptural and scholarly citations to prove her views wrong. Other unorthodox prescriptions, in their view, include allowing women to offer their ritual prayers in the same style as men, to lead those prayers, and to recite the Quran during the menstrual period (Shabbir 2009, Abu Safwan 2003). They object to Al-Huda's encouragement of women's work outside the home, even if the work involves spreading a religious message, and chastize them for allowing male teachers in front of women with covered faces but without a physical barrier dividing the classroom. Some are critical of Hashmi for not taking on her husband's last name, and accuse her of presenting all aspects of her own example as the authoritative model for women.

These ulama's vehement rejection of Al-Huda stems from a belief that only certain kinds of knowledge are appropriate for women. They expect the general population of Muslims to acquire only the fundamentals of Islamic knowledge covering rituals and obligations, and assign fathers and husbands the responsibility for ensuring that their female wards obtain this learning (Abu Safwan 2003: 47-60). They believe it is especially dangerous for women to attempt the translation and explanation of the Quran because of their limited understanding, and pointedly advise that women confine themselves to matters covered in the Bihishti Zewar ${ }^{20}$ (Abu Safwan 2003: 60). This hostility towards Al-Huda women's religious education is compounded by a suspicion of their privileged backgrounds, and many of the ulama pour scorn on Al-Huda gatherings as superficial meetings of fashionable women. They believe that the attractive presentation of religion at fancy locations is all that appeals to these women; the moral and spiritual benefits of instruction in mosques and madrasas are thought to be missing from the clubs and hotels' where they hold their classes (Abu Safwan 2003: 68).

These contestations are valuable in helping to chart the limits of Hashmi's authority by revealing where her personal and organizational claims are effective and where they fall short. The opposition from a male, professional class of religious experts is in many ways a struggle over who should be allowed to speak for the Islamic tradition. Material and symbolic resources are both at stake, as the ulama's mosques and madrasas compete for the same pool of private philanthropic funding that Al-Huda draws from. Both sides share many core beliefs and assumptions about the centrality of Islamic knowledge in the regulation of everyday life, and dispute the finer details in their interpretation of religious texts and practices. ${ }^{21}$ These competing claimants to Islamic religious authority hold each other to be in error, and 'the exaggeration of small differences... [turns] into emblems of group difference' (Collins 2001: 38).

\section{The liberal critique of an outdated orthodoxy}

33 In contrast to the traditionalist critics of Al-Huda, there are Pakistani men and women who are troubled more by Hashmi and her followers' appropriation of the Islamic tradition than by their modern pedagogical or organizational practices. Their fundamental objection is to the philosophy of this movement that seeks social reform

South Asia Multidisciplinary Academic Journal, 4 | 2010 
through the enforcement of religious practice and morality. Using arguments inspired by feminism, secular liberalism and alternative understandings of Islam, they criticize AlHuda on two counts: its dogmatic approach towards religion and limiting prescriptions for women. The urban, educated, upper- and middle-class profile of this group is similar to the backgrounds of most Al-Huda members, and Hashmi's credentials as a woman with a doctoral education do not disqualify her in their eyes as they do for the ulama. Instead this dispersed group of detractors challenges her moral narrative, the value of her contribution to women's lives, and her overstepping the bounds of scholarly authority.

These commentators highlight the proximity of Hashmi's interpretation of the Quran to conservative traditions within Islam, and the unquestioning acceptance of her views by her followers. Kamal (2001) describes herself as an educated woman from a 'Muslim Sufi background' who 'cannot accept that a single person can be the repository of so much diverse knowledge, wisdom and expertise'. She is perturbed by the 'zeal and selfrighteousness' of Al-Huda attendees 'spouting Farhat Hashmi's utterances as if they were the definitive word on Islam' (Kamal 2001). Another self-described Sufi Muslim woman (Koonj 2005) laments the 'closing of interpretive theological space' that results from Hashmi's claim to speak directly from God's words. This 'anti-intellectual' stance, according to the blogger Koonj, can lead to dangerous over-simplifications that pit those who are with Hashmi against all others who are 'against God'. Others echo the observation that Hashmi 'fails to recognize the essential flexibility of Islam, and that she is engaged more in developing a cult than encouraging a true understanding of religion' (Hyat 2001). Some suspect Hashmi of enriching herself and her family through financial manipulation while others blame her for creating disruptive changes in her followers' lifestyles and views, leading to broken marriages and households.

Some observers worry whether Al-Huda's conservative Islamic activism could lead to endorsement of, or participation in, radical forms of Islamic extremism. Obaid-Chinoy (2005) presents Al-Huda classes as a form of brainwashing, where 'students nod and murmur in agreement' and wall posters quoting Quranic passages give 'instruction on how Muslims should live their lives - guidance on when to smile, cry, tell the truth, when to be angry'. Like the ulama, this group of critics is disdainful towards the religiosity of rich Al-Huda women and suspects that their search for meaningful activities is just a passing fad, now that 'they have had their sleeveless blouses and coffee parties' (Ali 2003). Many complain that these women adopt rituals without grasping their meanings, and are obsessed only with trivial concerns-'issues like sitting or standing during a milad [a religious ceremony] or wearing nail polish during namaz [ritual prayer]' (Ibrahim 2001). They mock women who start wearing new styles of head and body covering for their shallow understanding of pious norms: 'Certainly, the 'hijab', often involving intricately wrapped headscarves, is more fashionable than going into 'purdah' or seclusion' (Hyat 2001).

36 The practice of veiling and segregation leads critics to believe that Al-Huda is teaching women to 'accept outdated gender roles' (Obaid-Chinoy 2005). They argue that Al-Huda classes offer a false sense of comfort and sisterly community, making it difficult for the members to recognize or feel outrage against the oppression faced by less privileged women. Kamal (2001) believes that women's activism cannot be meaningful unless it tackles 'the real problems faced by Pakistani women: death in the marital home, usurped inheritance, honor killings, trafficking of women, violence against women and sexual harassment'. While the ulama mostly disagree with the methods and female composition 
of Al-Huda, these liberal critics take issue with the very goals of the movement. For some of them, acquiring religious knowledge and individual self-discipline are not worthwhile objectives at all, while others believe that a moral awakening is complete only if its leads to a larger social good.

An inflammatory opinion frequently attributed to Hashmi is her acceptance of polygamy as a Muslim man's right and, more specifically, her encouraging women to 'let their husbands marry a second time so 'other sisters can also benefit" (Daily Times 2005). Many of the secular-liberal and moderate Muslim elites in Pakistan are skeptical about AlHuda's followers and what they perceive as misogynistic and self-righteous attitudes. These critics are ready to believe that Hashmi preaches women's subservience to their husbands. Hashmi, on the other hand, is keen to attract recruits from within this social group by presenting herself as a liberal and feminist interpreter of Islam. She explicitly denies accusations of advocating polygamy (Obaid-Chinoy 2005), and claims that she is protecting women's rights by arguing that the Quran orders a man to marry a woman with whom he has an illegal sexual affair. She frequently protests that her teachings inform women about the rights and dignity that Islam grants them (Obaid-Chinoy 2005, Ibrahim 2001). Hashmi's critics deploy a discourse of universal human rights to judge her leadership, and find it wanting in standards of morality as well as modernity. Al-Huda fails to impart the 'expansive, enlightened and empowering' message of the Quran, according to Hassan (2002), who dismisses Hashmi's 'modernist', 'liberalizing' and 'feminist' positions as mere public statements.

\section{Creating avenues for mobilization and reform}

Al-Huda's focus on study of the Hadith and understanding the Quran in its original Arabic is coupled with an emphasis upon judging one's own self and others in light of normative principles distilled from these texts. The significance of the movement's achievement lies in making a standard repertoire of reformist concerns-shared with the Ahl-i Hadith tradition of Islam-relevant and meaningful enough for these women that it starts shaping their actions.

Sadaf Ahmad (2009)'s anthropological study of Al-Huda women in Islamabad recognizes the movement's ability to shape members' ideas, conduct and relationships, but explains these changes with reference to individual biographies and large-scale cultural processes. In this account, exposure to Al-Huda's discourse can transform these individual women's subjectivities because they already possess the relevant cultural codes and values. What is missing in this explanation is the institutional moorings and collective dimension of cultural change. This is a limitation of the 'framing' approach (Snow et al 1986), which suggests that a social movement will find ready adherents if it frames its interpretations to resonate with pre-existing sets of beliefs. Mumtaz Ahmad (2010)'s examination of Farhat Hashmi's ideas and authority, on the other hand, finds her sophisticated use of electronic media to be a primary reason for her success. Yet, the television appearances or tapes and CDs have a limited transformative impact on their own. The process of learning to emulate a role model and insert her teachings into one's own life is an ongoing and painstaking one, and is facilitated in the group settings and face-to-face interactions in Al-Huda classrooms. It is through these ties of fellowship and loyalty to a group through which women can sustain their moral commitments, and feel themselves to be part of an authoritative consensus. 
There are numerous practices and techniques employed in Al-Huda classrooms that produce these results, for instance tailoring the commentary and illustrations towards the practical concerns and experiences of each specific audience, eliciting the active participation of students, and building supportive ties between them. Students learn to apply textual lessons to their own lives and engage in constant self-examination through devices that can be carried outside the classroom and inserted into daily routines, such as cassettes and duas (supplications, prayers) for various occasions. Course packets include checklists with a series of questions for periodic self-analysis, covering personal ethics, social relations, and religious obligations..$^{22}$

1 Several other providers of Islamic education in Pakistan-who are not part of the ulama fraternity nor trained in madrasas-have been active long before Al-Huda appeared on the scene. In addition to Jama'at-i-Islami's religious lessons and study circles, there have been pioneering individuals, like Dr. Israr Ahmad and Maulana Tahirul Qadri (Ahmad 2010, Phillipon 2006) who have made some space for women in their non-traditional Islamic teaching institutes. One of the ways in which Al-Huda stands out from these competitors is in its borrowing of structures and practices from formal education: dedicated campus buildings, admission and registration requirements, testing and grading of students, awarding of diplomas and certificates, teacher training and fixed syllabi. Farhat Hashmi's success is partly due to her timing, i.e. in tapping into the experiences and expectations of Pakistani women as they gained increased access to higher education over the 1980s and 1990s. Al-Huda's competitive advantage might not last very long as its rivals are already adapting and selectively emulating its methods. These include some former Al-Huda students, one of Farhat Hashmi's sisters (Nighat Hashmi), and other female instructors who have launched programs of religious study for women in Pakistani cities and who often consciously model themselves and their Islamic courses on Hashmi's example.

2 Farhat Hashmi is a significant female authority figure because the number of women in contemporary Pakistan holding doctoral degrees or leadership positions is still limited but, even more so, because she has acted as a 'cultural entrepreneur' (DiMaggio 1982) to create a viable social movement through which her religious ideas get disseminated. The critical reception for the movement and its female leader underscores just how unusual it is in the history of South Asian Islam for women to take up positions of religious authority.

Traditional institutions of Islamic learning and scholarly networks across the Muslim world have historically been dominated by men, with women rarely having access to scholarly credentials or formal positions of authority. Separate madrasas for women in the Indian Subcontinent are a recent, post-colonial innovation, and are subsidiary units of organizations run by men. Muslim women, who have held positions of religious leadership, have instead relied more easily upon charismatic authority, and Kalmbach (2008: 38, 41-42) points to a long history of female mystics who have headed Sufi networks and been entitled to inherit charismatic saintliness. In her study of contemporary Islamic activists in Syria, she finds that 'the authority of many female instructors is based more on reputation, teaching experience and personal style than on formal religious training' (Kalmbach 2008: 44). Family connections are particularly important for many of these women who benefit from the recognition and status that other (usually male) family members enjoy. Mahmood (2005: 65) similarly points out the lack of formal training for many women teaching in Cairo's contemporary mosque 
movement, claiming that 'the ability to practice $d a$ ' $w a$ [religious outreach] has come to depend not so much on doctrinal expertise as on one's moral uprightness and practical knowledge of the tradition'.

Hashmi invokes familiar forms of authority by mentioning her family background and asserting her personal moral probity, but displays her formal educational credentials even more prominently. Unlike many contemporary Islamic activists, she claims she can interpret and teach Islamic texts based not just on her practical knowledge but also on her years of study and research on Islam. Gaffney (1994: 30-35) argues that each title used for a contemporary Islamic teacher or preacher denotes a different local conception of knowledge (ilm), conveying the specific functions, degree of activism and social standing attached to that religious specialist. The Al-Huda movement literature emphasizes Hashmi's doctoral degree, and she is widely addressed by her title of 'Dr. Farhat Hashmi', ${ }^{23}$ linking her to specialized forms of modern knowledge and the prestige associated with them. Many of her followers are as impressed by her citation of multiple scholarly references as they are by her accessible idiom and ability to switch between Urdu, English and Arabic languages when she is delivering a lecture.

Modernists, Islamists, Tablighis ${ }^{24}$ and many others argue against the ulama's monopoly of Islamic learning based on the assumption that every individual has the capacity to understand and apply religious teachings. Hashmi has also adopted that line of reasoning and preaches it to her followers. In addition, she believes her own authoritative standing is enhanced by her specialized academic training and participation in transnational scholarly networks, enabling her to attack rivals' interpretations and the structures in which their learning is embedded. The very public context in which her teaching is conducted-classrooms, cassette recordings, media appearances-is a departure from traditional patterns of women providing religious instruction to other women in homes and private spaces. Men are in charge of the curriculum and administration at most madrasas for girls in India (Winkelmann 2005) and Pakistan (Farooq 2005), and at the helm of Islamist movements with women's wings like the Jama'at-i-Islami. In contrast, the key decision-making roles at Al-Huda are all filled by women. Hashmi's husband, Idrees Zubair, has been involved with Al-Huda from the beginning as a board member and teacher, but she is primarily responsible for the choices and the energy that have shaped the movement. In spite of this autonomy and absence of direct male control, there are gender-specific limitations that this women's movement has to either negotiate or accept.

Like other women venturing into public life, Hashmi has to strike a delicate balance between assertiveness in carving out new opportunities and compliance with existing norms of gender relations in Pakistan. Her strict observance of public veiling and frequent invocations of her own responsibilities as a mother, wife and daughter underscore her conformity with conservative social conventions. Nonetheless, as I showed above, her position leaves her open to attacks from both sides of the gender debate-from those who interpret it as a radical rupture of the status quo, and others who believe she is doing nothing to challenge women's subordination.

The organization of Al-Huda gatherings as female-only spaces, outside domestic or kinbased arenas, has provided many women the opportunities for mobility, sociability and leadership positions that were otherwise not available to them. By claiming to know more about Islam and citing authoritative religious texts in their original Arabic form, these women try to exert influence over male and female members of their families and 
communities, regardless of their age or customary positions. There are limits to the authority these women can claim in the religious sphere, and certain roles that have been traditionally performed by male religious experts are still reserved for men, i.e. delivering the Friday sermon or the call to prayer, or officiating as a prayer leader for men. Al-Huda opens up new possibilities of action and of imagining womanhood by introducing elite, educated women into structures of transmitting Islamic religious learning and encouraging them to lead busy, active public lives as moral agents. Whether they end up supporting liberal, feminist visions of women's liberation or undermining them, the changes wrought by this movement are already disrupting existing power relations and institutional arrangements in Pakistan.

\section{BIBLIOGRAPHY}

Abu Safwan, Mufti (ed.) (2003) Maghribi Jiddat Pasandi aur Al-Huda International [Western Modernism and Al-Huda International], Karachi: Jamhoor Ahl-i Sunnat wal Jamaat Pakistan.

Ahmad, Mumtaz (2010) 'Media-Based Preachers and the Creation of New Muslim Publics in Pakistan', in Mumtaz Ahmed, Dietrich Reetz \& Thomas Johnson (eds.), Who Speaks for Islam? Muslim Grassroots Leaders and Popular Preachers in South Asia, The National Bureau of Asian Research, Special Report, number 22.

Ahmad, Sadaf (2009) Transforming Faith: The Story of Al-Huda and Islamic Revivalism among Urban Pakistani Women, Syracuse: Syracuse University Press.

Ali, Sahar (2003) 'Pakistani Women Socialites Embrace Islam', BBC News Online, 6 November.

Collins, Randall (2001) 'Social Movements and the Focus of Emotional Attention', in Jeff Goodwin, James Jasper \& Francesca Polletta (eds.), Passionate Politics: Emotions and Social Movements, Chicago: University of Chicago Press.

Daily Times. 2005. 'Farhat Hashmi Operating in Canada', 6 May.

DiMaggio, Paul (1982) 'Cultural Entrepreneurship in Nineteenth-Century Boston: The Creation of an Organizational Base for High Culture in America', Media, Culture and Society, 4 (1), pp. 33-50.

Farooq, Muhammad (2005) 'Disciplining the Feminism: Girls' Madrasa Education in Pakistan', The Historian, 3 (2), pp. 64-88.

Gaffney, Patrick D. (1994) The Prophet's Pulpit: Islamic Preaching in Contemporary Egypt, Berkeley: University of California Press.

Gulf News. 2002. 'Scholar to hold Khatem-e-Quran', 1 December.

Hasan, Arif (1999) Understanding Karachi: Planning and Reform for the Future, Karachi: City Press.

Hassan, Riffat (2002) 'Islam and Human Rights in Pakistan: A Critical Analysis of the Positions of Three Contemporary Women', Media Monitors Network, URL: http://www.mediamonitors.net/ riffathassan1.html

Hirschkind, Charles (2006) The Ethical Soundscape: Cassette Sermons and Islamic Counterpublics, New York: Columbia University Press. 
Hussain, Mehvish (2000) 'In Search of Faith?', Herald, April.

Hyat, Kamila (2001) ‘Letter from Lahore: Hijab is New Fashion Statement among Wealthy', Gulf News, 7 March.

Ibrahim, Samina (2001) 'Interview with Farhat Hashmi’, Newsline, February.

Kalmbach, Hilary (2008) 'Social and Religious Change in Damascus: One Case of Female Islamic Religious Authority', British Journal of Middle Eastern Studies, 35 (1), pp. 37-57.

Kamal, Simi (2001) ‘The Farhat Hashmi Phenomena: A Critique’, Newsline, February.

Karachian (1999) 'Review’, Dawn, 20 December.

Khan, Sheema (2004) 'A Muslim Message More Irresistible than Hate', The Globe and Mail, 7 September.

Koonj (2005) ‘Dr. Farhat Hashmi in Toronto', URL: http://koonj.wordpress.com/2005/10/31/drfarhat-hashmi-in-toronto/

Lambek, Michael (1990) 'Certain Knowledge, Contestable Authority: Power and Practice on the Islamic Periphery', American Ethnologist, 17 (1), pp. 23-40.

Mahmood, Saba (2005) Politics of Piety: The Islamic Revival and the Feminist Subject, Princeton: Princeton University Press.

Matri, Shimaila (2003) 'The Opiate of the Elite', Newsline, December.

Meijer, Roel (ed.) (2009) Global Salafism: Islam's New Religious Movement, New York: Columbia University Press.

Munson, Ziad (2002) Becoming an Activist: Believers, Sympathizers and Mobilization in the American Pro-Life Movement, PhD Dissertation, Department of Sociology. Cambridge, MA: Harvard University.

Mushtaq, Faiza (2010) New Claimants to Religious Authority: A Movement for Women's Islamic Education, Moral Reform and Innovative Traditionalism, PhD dissertation, Department of Sociology, Evanston (Illinois): Northwestern University.

Obaid-Chinoy, Sharmeen (2005) ‘Islamic School for Women: Faithful or Fundamental?', The Globe and Mail, 29 October.

Philippon, Alix (2006) ‘Bridging Sufism and Islamism’, ISIM Review 17, pp.16-17.

Shabbir, Maulvi Muhammad (2009) 'Napaki ki halat mein talawat-i Quran aur aurat ki imamat ka hukam [Command on recitation of the Quran during a state of impurity and woman's leadership of ritual prayers]', AhleHaq, URL: http://ahlehaq.com/wordpress/?p=23

Shaheed, Farida (2002) Imagined Citizenship: Women, State \& Politics in Pakistan, Lahore: Shirkat Gah Women's Resource Centre.

Snow, David A.; Rochford Jr., E. Burke; Worden, Steven K.; Benford, Robert D. (1986) 'Frame

Alignment Processes, Micromobilization and Movement Participation', American Sociological Review, 51, pp. 464-81.

UNESCO (2004) Literacy Trends in Pakistan, Islamabad: United Nations Educational, Scientific and Cultural Organization.

Winkelmann, Mareike Jule (2005) From Behind the Curtain: A Study of a Girls' Madrasa in India, ISIM Dissertations, Amsterdam: Amsterdam University Press. 


\section{NOTES}

1. Al-Huda does not share official enrollment or attendance figures. My calculation is based upon interviews, my own visits to various sites, secondary accounts, and documents from early years of the organization.

2. Hashmi, Farhat interview by author, 17 August 2006, Toronto.

3. The deeds and sayings of the Prophet Muhammad, considered an authoritative source of guidance in Islamic jurisprudence.

4. This stance has also been described as Wahhabism-the official ideology of the Saudi Arabian state-and Salafism, a label for movements that seek to emulate the earliest community of Islam. These labels are contentious as they frequently entail accusations of extremism and foreign influence, and erasures of local histories.

5. The doctoral dissertation in sociology on which this article is based (Mushtaq 2010) contains a detailed discussion of data and methods.

6. An agricultural and trading town in the Punjab province of Pakistan.

7. An Islamist party in Pakistan which participates in national politics, and has an urban following. It was founded in India in 1941 by the influential ideologue, Syed Abul Ala Maududi.

8. A community of Muslims that forms a substantial minority in Pakistan where Sunni Muslims are the dominant majority.

9. One of the sub-divisions within Sunni Islam in South Asia, opposed by other Sunni factions like the Deobandis and the Ahl-i Hadith. Barelwis emphasize devotion to the Prophet Muhammad as well as other saints and spiritual mediators, and participate in rituals of shrine worship, music, singing and popular celebrations.

10. The outfit consists of a qamiz (long tunic) and shalwar (baggy trousers) that is standard attire for Pakistani women. The scarf is referred to as either a dupatta or chadar (a long unstitched piece of cloth, diaphanous or opaque) which can be draped around the shoulders or over the head and shoulders.

11. Names of all interviewees have been changed to preserve confidentiality.

12. See Ahmad (2009) for stories of altered lifestyles and family relations for individual women as a result of their involvement with Al-Huda in Islamabad.

13. Pakistan Employees Cooperative Housing Society. The acronym is more widely used.

14. E.g. in Lahore these are: Defence, Cavalry Grounds, Gulberg, Model Town, Johar Town, Iqbal Town, Shadman, Nespak, and Westwood.

15. They use both the English term and a roughly equivalent one in Urdu: 'parha likha tabqa'. Expressions like these are common outside the movement as well, and signify the social, cultural and economic privileges that access to formal education can grant in stratified Pakistani society. Shaheed (2002: 168) reports that the majority of Pakistani women in a national survey see 'inadequate or no education... as a basic reason for women's oppressed condition. Women therefore value and seek education as an enabling factor and as an end in itself'.

16. The old name of a lower-middle class Karachi neighborhood (currently Liaqatabad) figuratively associated with backwardness.

17. Al-Huda women tend to address each other by their names, and refer to Farhat Hashmi using terms such as 'Dr. Farhat' and ustazah (female teacher).

18. Religious scholars (usually male) with formal training in Islamic subjects who are qualified to teach but also perform a variety of legal, advisory, ritual and other functions.

19. Originally published in Urdu-language Islamic journals, like Zarb-e-Momin and Al-Balagh, or issued by the fatwa departments of prominent madrasas like Darul Uloom Korangi, Jamia 
Farooqia and Jamiat al-Ulum al-Islamiyya, Binori Town. These Karachi-based publications and institutions are all representative of the Deobandi school of thought in South Asian Sunni Islam.

20. Bihishti Zewar (Heavenly Ornaments) is a popular advice manual for Muslim women, written in the early $20^{\text {th }}$ century by Ashraf Ali Thanawi (1863-1943).

21. Despite some affinities between the Deobandi and Ahl-i Hadis schools of thought, as Ahmad (2009) suggests in her account of Al-Huda, there are serious and enduring lines of conflict between these two groups in South Asian history. The heated denunciations of Hashmi by her Deobandi critics pick on many of her signature Ahl-i Hadis positions. It is worth noting though, that most Al-Huda participants come from lay backgrounds and are not aware of these theological divides or sectarian labels that are attached to certain ritual practices and beliefs.

22. See chapter three of Mushtaq (2010) for an in-depth analysis of Al-Huda's organizational practices and classroom learning activities.

23. The title is frequently used by popular male preachers in Pakistan and India like Dr. Israr Ahmed or Dr. Zakir Naik who are qualified as medical doctors.

24. Members of the Tablighi Jamaat, a grassroots Islamic proselytizing movement of lay Muslims that began in India in the 1920s and now has a loosely networked global presence.

\section{ABSTRACTS}

Al-Huda is a movement of Islamic education and reform with a dedicated female following in Pakistani cities. Its founder and leader is a woman, Dr. Farhat Hashmi, who has become a wellknown public figure in Pakistan. This paper explores how Hashmi derives her authority, displays it, and defends it against challenges. Women who become active participants in her classes claim she transforms their understanding of Islam and inspires them to change their lives. However she is criticized by the secular-liberal elites of the country and by the traditional male leadership of Islamic institutions, who question her religious expertise and are uncomfortable with the role of both gender and class in this movement. This analysis highlights the collective interactions and organizational innovations through which Hashmi's teachings acquire an authoritative status for selected women.

INDEX

Keywords: Al-Huda, religious authority, Islam, education, organization, gender, social movements, Pakistan

\section{AUTHOR}

\section{FAIZA MUSHTAQ}

Visiting Research Fellow, Collective for Social Science Research, Karachi 